\title{
DYSF Gene
}

National Cancer Institute

\section{Source}

National Cancer Institute. DYSF Gene. NCI Thesaurus. Code C94680.

This gene plays a role in muscle contraction and plasma membrane dynamics. 